\title{
Sukcesja w firmie rodzinnej - droga do rozwoju czy upadku. Studium przypadku
}

\begin{abstract}
Tomasz Malesa*
Sukcesja to proces przekazywania przedsiębiorstwa następnemu pokoleniu. Jest zjawiskiem podtrzymujacym funkcjonowanie firm rodzinnych. Od niej zależy, czy przedsiębiorstwo się rozwinie, czy poniesienie klęskę. Temat sukcesji $w$ biznesie rodzinnym zostat $w$ niniejszym opracowaniu zanalizowany z uwzglednieniem najnowszej literatury naukowej $w$ tym zakresie. Głównym celem niniejszego artykułu jest przedstawienie procesu sukcesji w przedsiębiorstwie rodzinnym. Autor wykazuje przy tym, iż sukcesja jest procesem bardziej ztożonym niż przejęcie wtasności przez następców czy spadkobierców. Wymaga dokładnego i wieloetapowego planowania, uwzględniającego możliwie dtuga perspektywę czasowa.
\end{abstract}

Słowa kluczowe: sukcesja, dziedziczenie, sukcesor, przedsiębiorca, firma rodzinna.

Nadesłany: 11.06.2014 | Zaakceptowany do druku: 25.09.2014

\section{Succession in the Family business - The Way to Development or Decline. Case study}

Succession is the process of passing the enterprise on to the next generation. It is a phenomenon sustaining the long-lived life of family businesses and determining whether the company will develop or suffer defeat. Succession in family business is analyzed with regard to the newest scientific literature in this field. The main purpose of this article is to present the process of succession in the case study in one of the suburban businesses. The case study emphasizes that succession is a more complex process than taking possession of property. In addition, succession requires careful and multistage planning as well as should be perceived as a longterm process. Case study was conducted in detail. Various aspects of company's activities were taken into account in order to show the process of succession in the family business possibly broadest in scope.

Keywords: succession, inheritance, successor, entrepreneur, family business.

Submitted: 11.06.2014 | Accepted: 25.09.2014

JEL: D19, D22, D91, D92

\footnotetext{
Mgr Tomasz Malesa - doktorant w Katedrze Gospodarki Narodowej w Zakładzie Gospodarki Rynkowej, Wydział Zarządzania Uniwersytetu Warszawskiego.

Adres do korespondencji: Katedra Gospodarki Narodowej, Wydział Zarządzania Uniwersytetu Warszawskiego, ul. Szturmowa 1/3, 02-678 Warszawa; e-mail: tommal@onet.pl.
} 


\section{Wprowadzenie}

Dziedziczenie jest jedna z cech charakterystycznych dla firm rodzinnych. W celu zapewnienia ciagłości działania i utrzymania przedsiębiorstwa w rękach jednej rodziny każdy taki biznes wymaga uwzględnienia procesu sukcesji w swojej długookresowej strategii.

Głównym celem niniejszego artykułu jest przedstawienie procesu sukcesji na podstawie studium przypadku, z uwzględnieniem najnowszej literatury. Taka forma szczególnie wyraźnie pomaga podkreślić, iż sukcesja jest znacznie bardziej złożonym procesem niż proste przejęcie własności Autor postara się również odpowiedzieć na pytanie, czy sukcesja w przypadku badanego przedsiębiorstwa może doprowadzić do rozwoju, czy też upadku przedsiębiorstwa.

Istotą procesu sukcesji jest zarządzanie zmianą międzygeneracyjną (Marjański, 2010, s. 88). Oznacza to, że sukcesja w firmie rodzinnej wiąże się $\mathrm{z}$ przekazaniem przez założyciela lub właściciela kierowania firmą następcy, który może być członkiem rodziny lub zawodowym menadżerem (Surdej i Wach, 2010, s. 54). Z kolei inna definicja sukcesji mówi, że nie jest ona jednorazowym wydarzeniem związanym z przejeciem spadku, czy też przekazaniem całkowitej władzy lub jej części, lecz kluczowym elementem strategii rodzinnego biznesu (Budziak, 2012, s. 51-55). Pomimo dużego znaczenia tego procesu dla istnienia przedsiębiorstwa, wiele firm nie potrafi przeprowadzić go w sposób właściwy, co w konsekwencji może doprowadzić nawet do ich likwidacji.

W odniesieniu do firm rodzinnych należy podkreślić ich duże znaczenie dla gospodarki. Według szacunkowych danych PARP polskie przedsiębiorstwa rodzinne generują około 10\% PKB (Kowalewska, 2009, s. 57). Ponadto w ich działalności można dostrzec większe poczucie odpowiedzialności za losy firmy niż w przypadku tych o innej strukturze własności i zatrudnienia.

W niniejszym artykule przedstawiono proces sukcesji w przedsiębiorstwie rodzinnym działającym na terenie jednej z podwarszawskich miejscowości. Proces ów jeszcze trwa, dlatego też zaprezentowane zostaną jedynie jego zakończone etapy.

W artykule przestawiona została metodologia przeprowadzonego badania, historia firmy, opis członków rodziny oraz ich wpływu na działalność przedsiębiorstwa. Ponadto autor porusza kwestie związane z przebiegiem procesu sukcesji, czynnikami kluczowymi dla rozwoju badanego przedsiębiorstwa, a także wskazuje szanse oraz zagrożenia zachodzące podczas procesu sukcesji i w jego następstwie. Analizie zostaną poddane różne aspekty działalności oraz rozwoju przedsiębiorstwa podlegajacego sukcesji, z uwzględnieniem różnych modeli teoretycznych dotyczących firm rodzinnych oraz sukcesji w nich. Na koniec zostaną przedstawione wnioski.

\section{Specyfika sukcesji i firm rodzinnych}

Na początku należy podkreślić, że cechą odróżniającą przedsiębiorstwa rodzinne od innych jest fakt, że firma przez cały okres funkcjonowania jest prowadzona przez członków jednej rodziny. W celu zapewnienia ciągłości działania musi być ona zorientowana na długoterminowe planowanie. Wymiarami takiego planowania są: przyszłość, wytrwałość oraz ciągłość (Lumpkin i Brigham, 2011).

Naukowcy udowodnili również, iż firmy rodzinne są zdecydowanie mniej podatne na fluktuacje na rynku. U podstaw tej odporności leży kilka czynników, takich jak m.in.: orientacja długoterminowa, ugruntowana wiedza o przedsiębiorstwie, kapitał społeczny oraz lepsza identyfikacja potencjalnych szans na rozwój firmy (Chrisman, Chua i Steier, 2011).

Kolejnym wyróżnikiem przedsiebiorstw rodzinnych jest cel ich istnienia. W tabeli 1 przedstawiono cele ekonomiczne oraz nieekonomiczne biznesów rodzinnych i nierodzinnych.

Analiza tabeli 1 wskazuje, jak bardzo istotne dla gospodarki kraju sa przedsiębiorstwa rodzinne. Należy przy tym przede wszystkim podkreślić, że dla przedsiębiorstwa nierodzinnego głównym celem ekonomicznym jest maksymalizacja zysku. W przypadku firm rodzinnych dla właściciela najistotniejsze jest to, żeby prócz wysokich wyników finansowych oraz produkcyjnych lub handlowych zachować również pełną kontrolę nad przedsiębiorstwem zapewniając przy tym dobrobyt całej rodzinie. Różnice występują również w celach nieekonomicznych, firmy rodzinne dążą bowiem do osiagnnięcia harmonii rodzinnej, inne zaś do wewnętrznego spokoju. 
Tabela 1. Cele działania firm rodzinnych i nierodzinnych

\begin{tabular}{|l|l|l|}
\hline & \multicolumn{1}{|c|}{$\begin{array}{c}\text { Rodzina jako właściciele } \\
\text { - firmy rodzinne }\end{array}$} & \multicolumn{1}{c|}{$\begin{array}{c}\text { Właściciele spoza rodziny } \\
\text { - firmy nierodzinne }\end{array}$} \\
\hline $\begin{array}{l}\text { Cel } \\
\text { ekonomiczny }\end{array}$ & $\begin{array}{l}\text { - kontrola nad spółką, } \\
- \text { bogactwo rodziny, } \\
- \text { zapewnienie dobrobytu rodziny }\end{array}$ & $\begin{array}{l}\text { - główny cel - wzrost wartości firmy, } \\
\text { - wysokie wyniki - presja wyniku }\end{array}$ \\
\hline $\begin{array}{l}\text { Cel } \\
\text { nieekonomiczny }\end{array}$ & $\begin{array}{l}\text { - harmonia rodzinna, } \\
\text { - podniesienie statusu społecznego } \\
\text { rodziny }\end{array}$ & $\begin{array}{l}\text { - wewnętrzny spokój w firmie, } \\
\text { - stosunki zewnętrzne }\end{array}$ \\
\hline
\end{tabular}

Źródło: opracowanie własne na podstawie Kotlar i De Massis (2011, s. 1263-1288).

W kontekście gospodarki firmy rodzinne są bardziej stabilne, ponieważ dla ich właścicieli i członków bardziej liczy się dobro rodziny niż ryzykowna maksymalizacja zysku. Oczywiście, nie można postawić tezy, że firma rodzina nie dąży do maksymalizacji zysku, jednak podejmowane przez nią działania uwzględniają też w dużym stopniu aspekty rodzinne. Dzięki temu właśnie inwestycje najczęściej są mniej ryzykowne.

Warto też zauważyć, że członkowie rodziny muszą znaleźć miejsce w firmie i dzięki temu nie poszukują zatrudnienia gdzie indziej oraz nie powiększają rzeszy bezrobotnych. Rysunek 1, zaczerpnięty $\mathrm{z}$ publikacji pt. Generation to Generation Life Cycles of the Family Business, pokazuje trzy okręgi wzajemnie zachodzące na siebie (własność, rodzina, przedsiębiorstwo). Odpowiadają one podziałowi na grupy najważniejszych interesariuszy przedsiębiorstwa względem pozycji zajmowanych w firmie rodzinnej.
Rysunek 1. Model systemu przedsiębiorstwa rodzinnego

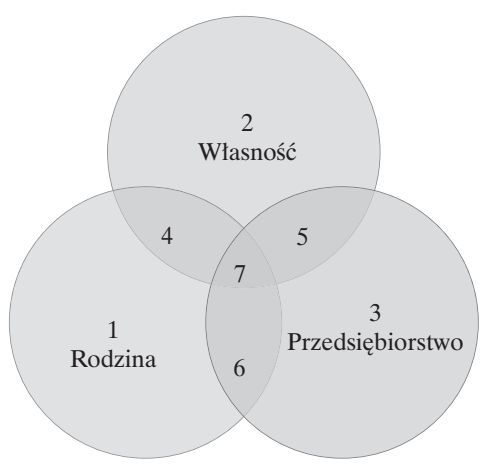

Źródło: opracowanie własne na podstawie Gersick, Davis, McCollom i Lansberg (1997, s. 6).

Analizując rysunek 1, można zauważyć, że jedynie osoby stanowiące grupę interesariuszy oznaczoną numerem 7 są członkami rodziny i jednocześnie mają prawa

Rysunek 2. Kluczowe czynniki wpływające na proces sukcesji

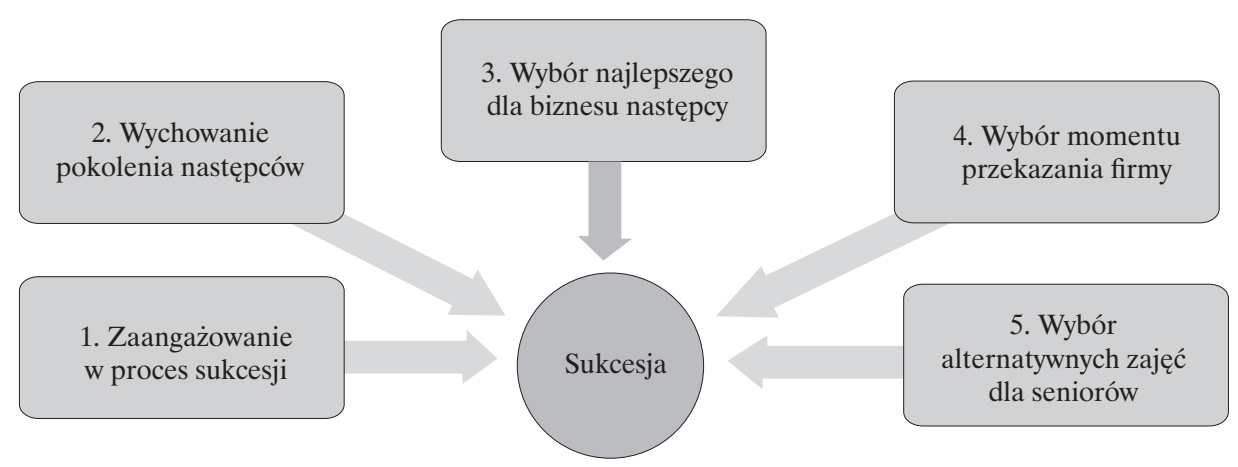

Źródło: opracowanie własne na podstawie Lewandowska, Greser i Jakubowski (2012, s. 126).

Wydział Zarządzania UW ～DOI 10.7172/1733-9758.2015.18.7 
własności oraz uczestniczą w życiu przedsiębiorstwa.

Rozpoczynając analizę procesu sukcesji, warto również zaprezentować rysunek 2, pokazujący kluczowe czynniki wpływające na jego poprawność i skuteczność.

Rysunek 2 podkreśla tezę postawioną we wstępie artykułu, że proces sukcesji wymaga wieloetapowego i wieloaspektowego planowania, tzn. wybór najlepszego z możliwych sukcesorów nie zapewni powodzenia całego procesu dziedziczenia (np.: może to być osoba niezaangażowana w życie firmy bądź nieprzystosowana do uczestniczenia w nim). Podobnie wygląda sytuacja w przypadku seniorów. Ważne jest, żeby jasno określić miejsce, które będą oni zajmowali po sukcesji. Brak wyraźnie określonego zakresu współpracy może doprowadzić do międzypokoleniowych kontrowersji i braku spójności wizji, a w konsekwencji do problemów z zarządzaniem przedsiębiorstwem.

Najbardziej klasyczne i udokumentowane podejście do podziału procesu sukcesji na etapy polega do wyodrębnienia siedmiu faz: przedbiznesowej, wprowadzającej w biznes, wprowadzajacej funkcjonalnej, funkcjonalnej, zaawansowanej funkcjonalnie, wczesnej sukcesji oraz dojrzałej sukcesji (Longenecker i Schoen, 2002).

$\mathrm{Na}$ rysunku 3 przedstawiono proces sukcesji w sposób bardziej klarowny. Taki podział został przyjęty przez J. Jeżaka, W. Popczyk oraz A. Winnicką-Popczyk. (Jeżak, Popczyk, Winnicka-Popczyk, 2004, s. 60-61).

Rysunek 3. Etapy procesu sukcesji

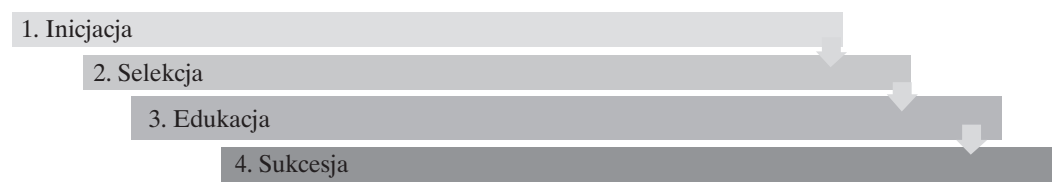

Źródło: opracowanie własne na podstawie Jeżak, Popczyk i Winnicka-Popczyk (2004, s. 60-61).

Inicjacja to czas, kiedy dzieci zapoznają się z działalnością przedsiębiorstwa, wdrażają się w różne aspekty jego funkcjonowania po to, by poznać dogłębnie dziedzinę, którą zajmuje się firma rodzinna. Po zaszczepieniu młodemu pokoleniu chęci uczestnictwa w życiu przedsiębiorstwa przychodzi czas na selekcję, czyli proces wyłaniania najlepszych potencjalnych kandydatów do przejęcia władzy w przedsiębiorstwie. Proces selekcji zawsze jest uwarunkowany specyfika młodego pokolenia. Im większa jest liczba prawdopodobnych sukcesorów, tym kryteria oceny ich kwalifikacji i predyspozycji są znacznie bardziej rozbudowane. Dodatkowo nowicjusze sa oceniani pod kątem swojego zaangażowania w działalność firmy. Głównym celem tego etapu jest zawężenie grona potencjalnych nasteppów do kilku osób. Po wytypowaniu tych, które stwarzają największe nadzieje, następuje proces edukacji polegający na rozwijaniu różnego rodzaju umiejętności służących do samodzielnego kierowania przedsiębiorstwem. W tym eta- pie potencjalni następcy poszerzają wiedze dotyczącą technik zarządzania i planowania strategicznego oraz poznają tajniki działania przedsiębiorstwa. Gdy osiągną oni odpowiedni poziom wykształcenia naukowego i posiądą wszystkie umiejętności pozwalające na przejęcie przedsiębiorstwa, następuje ostatni etap, czyli sukcesja. $\mathrm{Na}$ końcu senior odchodzi albo pozostaje na uboczu, mając zazwyczaj głos doradczy, zaś młode pokolenie przejmuje władzę i własność przedsiębiorstwa. Jak łatwo zauważyć, podejście zaprezentowane w publikacji polskich autorów opisuje wszystkie 7 faz przedstawionych przez Longeneckera oraz Schoena, jednak w sposób bardziej ogólny.

Kolejnym istotnym aspektem dotyczacym procesu dziedziczenia są jego obszary krytyczne, najbardziej istotne dla przetrwania oraz bieżącego funkcjonowania przedsiębiorstwa. Według T. Budziaka podczas planowania przejęcia firmy w drodze sukcesji można wyróżnić trzy obszary krytyczne, pokazane na rysunku 4. 
Rysunek 4. Obszary krytyczne w procesie planowania sukcesji

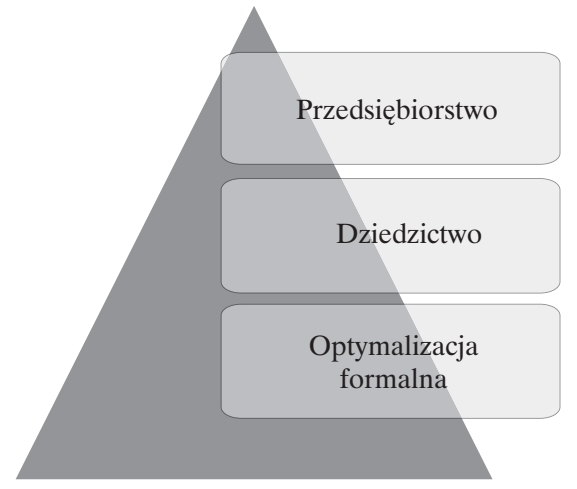

Źródło: opracowanie własne na podstawie Budziak (2012, s. 79).

Na wstępie należy zaznaczyć, iż wszystkie trzy obszary są ze sobą skorelowane i wzajemnie siebie dotyczą. Przede wszystkim obecni właściciele musza zrobić wszystko, aby przekazać przedsiębiorstwo bez żadnego uszczerbku dla jego funkcjonowania. Dziedzictwo jest związane z niezwykle trudnym aspektem funkcjonowania rodziny biznesowej, ponieważ dotyczy połączenia życia prywatnego z życiem firmy. Sukcesja, jako element składowy całego dziedzictwa pokoleniowego, musi być tak przeprowadzona, aby zapewniała odpowiedni ład rodzinny. Kolejnym kluczowym obszarem jest formalna optymalizacja procesu. Niestety, przepisy podatkowe oraz inne uwarunkowania prawne powoduja, że nierozważny, lekkomyślny plan przeprowadzenia sukcesji może doprowadzić do rozpadu przedsiębiorstwa. Zgodnie $\mathrm{z}$ naukowym podejściem, najbardziej istotnym obszarem jest przedsiębiorstwo, potem dziedzictwo, a na końcu optymalizacja formalna. W rzeczywistości jednak sposób myślenia o kluczowych aspektach jest całkowicie odwrotny i przedsiębiorcy najpierw myśla, jak zoptymalizować proces sukcesji pod kątem finansowym (podatki), a dopiero potem zastanawiają się, jaki wpływ ma dziedziczenie na całą firmę.

Krytyczne, według T. Budziaka, są między innymi aspekty bezpośrednio związane z seniorem oraz potencjalnym sukcesorem. Pierwszym jest odpowiedź na pytanie, jak dokonać wyboru właściwego sukcesora (2012, s. 130). Wiąże się z tym analiza potencjalnego następcy pod różnymi wzglę- dami (czy następca poradzi sobie psychicznie $\mathrm{z}$ ciężarem przejęcia przedsiębiorstwa, czy jego wiedza jest wystarczająca, czy pozycja w rodzinie jest odpowiednio stabilna i zapewniajaca przetrwanie biznesu nawet w kryzysie). Mogą się także pojawić problemy ze strony seniora (obecnego właściciela), polegające na trudnościach z zaakceptowaniem decyzji o sukcesji. Czasami też obecni właściciele starają się ukształtować młode pokolenie na swój wzór, co powoduje u juniorów niechęć, a w konsekwencji konflikty. Po wyszkoleniu następcy pojawia się kolejne pytanie, czy senior będzie umiał odejść. Łatwo jest deklarować, iż nadszedł czas, żeby odejść, ale na pewno dla ludzi, którzy są związani całe życie z przedsiębiorstwem taka decyzja nie jest łatwa, ani jednoznaczna. Zawsze będą czuli przywiązanie do swojej firmy. Ostatnim, wyróżnionym przez Budziaka, kluczowym obszarem jest odpowiedź na pytanie, czy biznes jest przygotowany do przejeccia. Czy obecna sytuacja na rynku, w rodzinie pozwala na dokonanie sukcesji?

Pozytywna odpowiedź na każde pytanie utwierdza w przekonaniu, że nadszedł czas, żeby przekazać przedsiębiorstwo.

\section{Metodologia badania}

Informacje będące podstawą artykułu pochodzą z wywiadów nieustrukturalizowanych $\mathrm{z}$ członkami rodziny zaangażowanymi w życie firmy oraz doświadczenia autora w zakresie funkcjonowania opisywanego przedsiębiorstwa. Metoda badawcza wykorzystaną w poniższym artykule jest też studium przypadku. Wybór studium przypadku jest nieprzypadkowy, ponieważ jest to metoda kompleksowa, która zapewnia połączenie kilku bardziej szczegółowych metod badawczych (m.in. wywiadów nieustrukturalizowanych oraz obserwacji uczestniczacej (Kostera, 2003, s. 101-142). Studium przypadku ma na celu zestawienie teorii dotyczącej procesu sukcesji z sytuacją badanego przedsiębiorstwa (Czakon, 2011, s. 48-59) oraz udzielenie odpowiedzi, czy sukcesja prowadzi do rozwoju czy upadku przedsiębiorstwa.

Wywiady zostały przeprowadzone ze wszystkimi członkami firmy rodzinnej na poczatku 2014 roku. Nie miały one sztywnej struktury i nie były rejestrowane. Najważniejsze kwestie zostały zanotowane i opisane w zaprezentowanym studium 
przypadku. Rozmowy trwały kilka dni, po 2-3 godziny dziennie. Podczas rozmów zostały poruszone najważniejsze kwestie związane $\mathrm{z}$ procesem sukcesji badanego przedsiębiorstwa. Zakres rozmów był ukierunkowany na trwający w firmie proces sukcesji. W celu zrozumienia zależności występujących w firmie zostały poruszane kwestie historyczne oraz plany właściciela na przyszłe lata. Doświadczenie autora wynika z obserwacji uczestniczącej. Od 5 lat autor uczestniczy w życiu przedsiębiorstwa poprzez obserwacje życia oraz kluczowych decyzji podejmowanych przez przedsiębiorstwo.

Uzasadnieniem dla wyboru powyższych metod jest ich dostępność oraz bardzo dobre dopasowanie do charakteru tego studium przypadku. Warto jednak na wstępie podkreślić, iż część danych może mieć charakter subiektywny, co wynika z faktu, że autor jest członkiem opisywanej firmy rodzinnej. Nazwa firmy oraz imiona członków rodziny zostały zmienione aby zapewnić ustalony z właścicielem poziom anonimowości.

\section{Charakterystyka firmy}

Przedmiotem analizy jest przedsiębiorstwo rodzinne, mające siedzibę w jednej z podwarszawskich miejscowości. Firma działa już dwadzieścia pięć lat. Zasięg działania to głównie lokalny rynek. Kluczowy z punktu widzenia analizy jest fakt, że wyróżniają ją mocne więzy rodzinne.

Głównym profilem działalności firmy Romex jest wynajem nieruchomości. Czynsze otrzymywane w zamian za udostępnianie lokali sa głównym źródłem dochodu. W ramach przedsiębiorstwa prowadzona jest także myjnia samochodowa. Długoletnia działalność pozwoliła na zbudowanie dużej lojalności klientów i wykreowanie silnej marki. Kolejną wartością dodaną jest dla przedsiębiorstwa lokalizacja: centrum miasta. Ponadto lokale na wynajem oraz myjnia są położone w odległości ok. $200 \mathrm{~m}$ od siebie, co umożliwia właścicielowi pełną kontrolę nad działalnością.

Tak zróżnicowany profil działalności firmy wynika z faktu, że początkowo jedynym jej elementem była myjnia samochodowa. Rozpoczynając działalność, przedsiębiorstwo było jedyną tego typu firmą na rynku. Aktualnie w okolicy powstało 9 konkurencyjnych firm, z czego 3 myjnie samoobsługowe, stanowią najpoważniejsze zagrożenie. Jednak czujność, stała obserwacja lokalnego rynku, a może przede wszystkim talent właściciela do podejmowania strategicznych decyzji, pozwoliły na permanentne dopasowywanie profilu działalności do lokalnego popytu.

Majątek firmy to efekt wieloletniej pracy małżeństwa odpowiedzialnego za funkcjonowanie przedsiębiorstwa. Aktualnie w przedsiębiorstwie zatrudnione są 3 osoby (w myjni) oraz firmy zewnętrzne realizujące zlecone zadania (prace administracyjne związane z obsługą wynajmowanych lokali). Liczba pracowników świadczy, że zgodnie z przyjętą klasyfikacją wg zaleceń Unii Europejskiej (Zalecenie Komisji z dnia 6 maja 2003 r. nr 2003/361/EC) analizowane przedsiębiorstwo możemy zaliczyć do mikroprzedsiębiorstw, bowiem suma rocznych obrotów nie przekracza 2 mln euro.

Członkowie rodziny stanowią nieformalne wsparcie dla właścicieli w obsłudze przedsiębiorstwa (m.in. obsługa prawna, przygotowywanie ofert, odbiór towarów itd.). Obecnie potencjalni sukcesorzy nie są zatrudnieni w przedsiębiorstwie, lecz pracują w dużych korporacjach bądź studiują. Trzeba też podkreślić, że przedsiębiorstwo, pomimo stabilnej pozycji, nie należy do największych. Stąd też można uznać za prawdziwe słowa E. Stavrou (1999, s. 52), że istnieje dodatnia korelacja pomiędzy wielkością przedsiębiorstwa a chęcią dzieci właścicieli do przejęcia firmy.

Jeżeli przedsiębiorstwo wymagałoby poświęcenia większej ilości czasu, to na pewno potencjalni sukcesorzy nie szukaliby zatrudnienia w większych firmach, tylko zajęli się jego prowadzeniem. Członkowie rodziny chcą kontynuować to, co zapoczątkował obecny właściciel i dalej rozwijać firmę.

\section{Historia firmy}

Historia przedsiębiorstwa jest opisana w sposób dość szczegółowy, ponieważ autor odnosi się do niej w kolejnych częściach artykułu. Poza tym jest to niezbędne dla potwierdzenia tezy, że sukcesja jest procesem długofalowym.

Początki działalności datowane są na rok 1989. Należy zaakcentować, że życie firmy jest dość mocno skorelowane z życiem całej rodziny właściciela.

W momencie założenia przedsiębiorstwo było nastawione na świadczenie usług 
transportu oraz robót ziemnych. Wcześniej właściciel prowadził biznes ze swoim bratem, wtedy jeden odpowiadał za stronę techniczną przyjmowanych zleceń, drugi zaś za negocjowanie kontraktów oraz obsługe biurową całej firmy. Wspólne przedsiębiorstwo trudniło się wykonywaniem przyłączy sanitarnych i kanalizacyjnych w domach mieszkalnych i innych budynkach. Zyski właściciel zainwestował $\mathrm{w}$ rozwój własnej firmy (zakup koparek, samochodu ciężarowego i narzędzi niezbędnych do realizacji zamówień). W roku 1989 i 1990 urodzili się dwaj synowie, co spowodowało, że małżonka musiała zająć się opieką nad nimi.

Po transformacji ustrojowej $\mathrm{z}$ roku na rok liczba firm transportowych oraz świadczących usługi budowlane zaczęła rosnąć zdecydowanie szybciej niż popyt na te usługi. W związku z tym, chcac uniknąć likwidacji przedsiębiorstwa, właścicie zaczął myśleć o zmianie branży. Zdecydował o otwarciu myjni samochodowej bliżej miejsca zamieszkania. Decyzja zbiegła sie z datą urodzin trzeciego dziecka w 1994 roku. $\mathrm{Z}$ czasem działalność transportowa powoli traciła znaczenie, ponieważ liczne firmy z dużo większym kapitałem przejmowały zlecenia. W 1995 r. cały ciężki sprzęt został sprzedany. Pieniądze uzyskane ze sprzedaży właściciel zainwestował w nieruchomości rolne oraz budowę kolejnych 3 stanowisk w myjni. W tamtym okresie firma zatrudniała 7 pracowników.

Duże zaangażowanie w działalność biznesową oraz bardzo wysoki popyt na usługi skutkowały przychodami o takim poziomie, który pozwolił na następne inwestycje. Z uwagi dobre relacje sasiedzkie w 1999 r. właściciel nabył kolejną część nieruchomości (kamienice) będacej przy zakładzie. Inwestycja była dla niego szczególnie interesująca, ponieważ oprócz tego, że miała dużą wartość materialną, nadawała się do wynajmowania. Pomysł rozszerzenia działalności o wynajem lokali był zatem naturalna konsekwencją transakcji, a jednocześnie spowodował znaczące przyspieszenie rozwoju przedsiębiorstwa.

Sukces, jaki odniosły myjnie samochodowe, wyzwolił reakcję konkurencji i powstanie $\mathrm{w}$ miejscowości kolejnych takich punktów. Właściciel, świadomy faktu, iż konsumpcyjny tryb życia nie zapewni dobrobytu następnym pokoleniom, zadecydował o lokowaniu znacznej części przychodów w grunty rolne. W roku
2005 rozpoczął się proces przekształcania zakupionych wcześniej gruntów rolnych w grunty budowlane, a następnie zostały one sprzedane. Po dokonaniu transakcji pojawił sie pomysł rozbudowania wcześniej kupionych nieruchomości. Celem rozbudowy było stworzenie większej liczby lokali do wynajęcia. W 2007 roku, kiedy rozpoczęła się kolejna budowa, sytuacja gospodarcza na miejscowym rynku była bardzo dobra. Jeszcze przed ukończeniem budowy wszystkie lokale zostały wynajęte. Spowodowało to, że motywacja do realizacji kolejnej inwestycji była bardzo duża. Została ona zrealizowana w 2009 roku. Nastepnym punktem zwrotnym była inwestycja dokonana w 2011 roku. Obejmowała ona zakup budynku do remontu, w dobrej lokalizacji. Znajdował się on bowiem w odległości $50 \mathrm{~m}$ od posiadanych działek.

Dzisiaj firma skupia się głównie na rynku nieruchomości. Myjnia samochodowa ma raczej charakter dodatkowy.

\section{Członkowie rodziny}

Członkowie rodziny mają wpływ na kreowanie wartości firmy i każdy z nich odgrywa określoną rolę. Bez nich proces sukcesji nie miałby sensu.

Pierwszą i najważniejszą osobą jest właściciel, w wieku 55 lat, ciągle aktywny zawodowo. $\mathrm{Z}$ uwagi na bardzo duże zainteresowanie motoryzacją postanowił kontynuować naukę w tym kierunku. Od razu po zakończeniu edukacji rozpoczął pracę we własnej firmie. Jak wynika z relacji rodziców właściciela: „Był przedsiębiorczy, tu kupil, tam sprzedał, tu dołek wykopał, tu coś przewiózł. Nigdy nie było tak, żeby nie miał jakiegoś zajecia". Mimo to fakt, że obecny właściciel nigdy nie chciał pracować dla kogoś, był wielkim zaskoczeniem dla jego rodziców, mających nadzieję na kontynuowanie przez niego zawodu ojca - szanowanego geodety $\mathrm{w}$ jednym $\mathrm{z}$ warszawskich przedsiębiorstw geodezyjnych. Opisując właściciela, trzeba podkreślić jego upór w dążeniu do celu oraz przywiązanie do tradycyjnego modelu rodziny, w którym ponad wszystko stawia się jej dobro. Stąd wspomniana decyzja o rezygnacji z firmy transportowej na rzecz myjni samochodowej. Przedsiębiorca ten, gdy postawił sobie za cel rozbudowę budynku o kolejne lokale na wynajem, robił wszystko, by cel ten zrealizować, często mimo przeciwności losu. 
Jako przykład może posłużyć dwuletnia batalia $\mathrm{z}$ sąsiadką $\mathrm{w}$ sprawie pozwolenia na budowę. Jak sam przyznaje: „Nie osiagną bym tego, gdyby nie Maria” (małżonka).

Małżonka, z zawodu technik analityk (laborantka), jest o rok młodsza od przedsiębiorcy. Podczas drugiego roku studiów medycznych zmarła jej matka. Uniemożliwiło to kontynuacje nauki, bowiem wymagało od niej zaangażowania się $\mathrm{w}$ opiekę nad dwójką młodszego rodzeństwa. Wrodzona opiekuńczość oraz mocne przywiązanie do wartości rodzinnych nie pozwalały jej na zostawienie rodziny samej. Ponadto stanowiła ona oparcie dla młodszego rodzeństwa, zastępując im matkę. Dodatkowo jednak, mimo licznych obowiązków domowych, Maria pracowała jako laborantka w jednym $\mathrm{z}$ miejscowych szpitali. Gdy młodsze rodzeństwo stało sie samodzielne, Maria z Kazimierzem wzięli ślub, zaś po urodzeniu się pierwszego dziecka, postanowili, iż poświęci się ona jego wychowaniu. Maria nigdy nie dążyła do bezpośredniego uczestniczenia $\mathrm{w}$ działalności firmy. Stała jednak u boku męża, wspierając go w trudnych okresach. Miała też w konsekwencji pośredni wpływ na przedsiębiorstwo poprzez sposób wychowania dzieci. Wszystkie jej cechy osobowościowe były doskonałym wzorcem do kształtowania ich charakterów. Tak jak w pierwotnej rodzinie, tak i u jej dzieci wytworzyła się silna wzajemna więź.

Potencjalnymi sukcesorami biznesu rodzinnego są: Tobiasz, Piotr i Anna. Oni zostaną zatem opisani pod kątem cech charakteru oraz osobowości przydatnych do przetrwania przedsiębiorstwa.

Piotr jest absolwentem uczelni ekonomicznej oraz prawniczej, pracownikiem jednej z firm zajmujących się $\mathrm{w}$ doradztwem i konsultingiem. Jest bardzo stonowaną osobą, na chłodno wyrażającą swoje opinie. Jego decyzje są zawsze przemyślane, pewne oraz obarczone niskim ryzykiem niepowodzenia. Można powiedzieć, że jest perfekcjonistą. Mniej więcej od ukończenia szkoły podstawowej pomaga ojcu w prowadzeniu rodzinnej firmy. $\mathrm{Z}$ biegiem czasu coraz głębiej poznawał przedsiębiorstwo dzięki temu, że udostępniano mu różnego rodzaju dokumenty, w tym finansowe; był też wprowadzany we wszystkie aspekty działania firmy. Sukcesywnie staje się coraz lepszym finansistą i stanowi poważne wsparcie dla przedsiębiorstwa ze względu na posiadaną wiedzę $\mathrm{z}$ zakresu ekonomii. Od pierwszego roku studiów jest również odpowiedzialny za stronę prawną prowadzenia firmy. Do jego obowiązków należy miedzy innymi redagowanie pism urzędowych oraz ofert dla przedsiębiorców. Ponadto pomaga optymalizować strategię podatkową przedsiębiorstwa poprzez umiejetne wykorzystywanie przepisów. W celu pogłębienia wiedzy zdecydował, że dopóki nie ukończy aplikacji radcowskiej, bedzie pracował w innej firmie, gdzie specjalizuje się w prawie podatkowym. Po tym okresie zamierza przejąć z bratem przedsiębiorstwo rodzinne i zmienić profil działania na doradczo-inwestycyjny. Zgodnie z planami zajmie się działalnością doradczą, podczas gdy młodszy brat - inwestycyjną. Wspólne tworzenie biznesu będzie miało na celu wzajemne uzupełnianie się oraz kompleksową obsługę przedsiębiorstw od strony podatkowej i inwestycyjnej.

Tobiasz to absolwent uczelni ekonomicznej, pracownik jednej z firm państwowych. Opis Tobiasza jako członka rodzinnego biznesu został sporządzony przez brata Piotra

„Tobiasz jest zdecydowanie bardziej przedsiębiorczy ode mnie - swoje podejście do biznesu odziedziczył po tacie, ja zaś chyba charakter mam bardziej po mamie. Zawsze ma dobre pomysły. Aczkolwiek czasami ma problem $\mathrm{z}$ tym, że chciałby robić kilka rzeczy w jednym momencie. Jako starszy brat czuwam nad tym i zawsze wspieram go w realizacji jego pomysłów. Od kiedy pamiętam zawsze razem się uzupełnialiśmy. Czy to podczas gry w piłkę, w szkole, przed rodzicami, zawsze byliśmy zgranym zespołem. Podobnie jest teraz w przedsiębiorstwie, pomimo że obaj pracujemy, zawsze znajdziemy czas, żeby poszukać dla taty kolejnej inwestycji. Nie ukrywam, że zależy nam, aby tata podejmował trafne decyzje, bo przecież kiedyś my będziemy zarządzać tym majątkiem. Czesto też dyskutujemy razem nad różnego rodzaju ofertami handlowymi dla innych przedsiębiorstw. Tobiasz albo tata przedstawiają pomysł, razem spisujemy najważniejsze kwestie, uzgadniając je ze wszystkimi członkami rodziny, ostatecznie zawsze oficjalnie musi zaakceptować mama, a podpisać tata. Patrząc przez pryzmat roli, jaką odgrywamy w przedsiębiorstwie, Tobiasz jest raczej osobą bardzo przekonującą do swoich racji. Często jego pomysły po drobnej modulacji są bardzo dobre. Ważne jest 
to, że mamy jasny podział ról, ja zajmuję się sprawami np. prawnymi, on organizacyjnymi. To on zawsze wie, jak zrealizować pomysł, żeby wszystko było na czas. Podejrzewam, że po oficjalnym przejęciu przedsiębiorstwa taki podział ról się zachowa. $\mathrm{Na}$ koniec chciałbym tylko dodać, że już zaczęliśmy współpracować, żeby zobaczyć, czy wspólny biznes będzie dla nas szczęściem, czy utrapieniem. Prowadzimy razem klub sportowy, do którego przeniesiony został podział z firmy rodzinnej. Po pół roku działalności mogę powiedzieć, że naprawdę Tobiasz to najlepszy wspólnik, jakiego mogłem sobie wymarzyć. Poza tym, analizując jego charakter oraz pomysłowość, sądzę, że do trzydziestki będziemy prowadzić już wspólną działalność. A wracając do sukcesji w naszym przedsiębiorstwie, myślę, że wiele aspektów jest już znanych, jedyną niewiadomą jest dokładny termin formalnego przekazania przedsiębiorstwa".

Ostatnią osobą, najmniej zaangażowaną w działalność rodzinnego przedsiębiorstwa, jest Anna, studentka pierwszego roku uczelni ekonomicznej. Wynika to przede wszystkim $\mathrm{z}$ tego, że jest najmłodszym członkiem rodziny. Anna w firmie podejmuje raczej rolę doradczą, ponadto bardzo dobrze wykonuje wszystkie powierzone jej zadania, co najprawdopodobniej zawdziecza zdolnościom organizacyjnym odziedziczonym po ojcu.

$\mathrm{Z}$ uwagi na to, że właściciel przedsiębiorstwa przywiązuje dużą wagę do tradycji rodzinnych, przy każdej okazji przypomina synom o tym, by pamiętali o siostrze.
Odnosząc sytuację analizowanego przedsiębiorstwa rodzinnego do zachodzących na siebie trzech okręgów (własność, rodzina, przedsiębiorstwo), przedstawionych na rysunku 1, możemy zaklasyfikować wyżej wymienionych członków rodziny do określonych grup (oznaczonych wymienionym schemacie cyframi od 1 do 7).

Właściciel jest osobą, która znajduje się w centrum (nr 7). Jest on zarówno członkiem rodziny, jak i jedyną osobą prawnie odpowiedzialną za całą firmę. Maria, mimo że ma duży wpływ na podejmowane decyzje, nie jest formalnie współwłaścicielem przedsiębiorstwa, dlatego też można ją zaklasyfikować do grupy nr 6. Podobnie jest w przypadku dzieci. Tobiasz i Piotr uczestniczą w życiu przedsiębiorstwa, ale nie mają w nim żadnego udziału (nr 6). Annę natomiast możemy jedynie zaklasyfikować do grupy nr 1 jako członka rodziny. Schemat ów udowadnia, że właściciel ma największą moc decyzyjną, a Maria, Tobiasz i Piotr są doradcami.

\section{Analiza procesu sukcesji w przedsiębiorstwie rodzinnym Romex}

Przedsiębiorstwo Romex jest stosunkowo młode (przypomnijmy, że ma dopiero 25 lat), jeśli odniesiemy to do innych firm, jak choćby Fonjallaz Wein, która jest w rękach jednej rodziny od 1552 r. (http://kodywartosci.pl/kw_raport.pdf, data dostępu: 14.02.2014). Proces sukcesji będzie w tym przedsiębiorstwie dokonywany dopiero

Rysunek 5. Kluczowe pytania i odpowiedzi dotyczące sukcesji w przedsiębiorstwie Romex

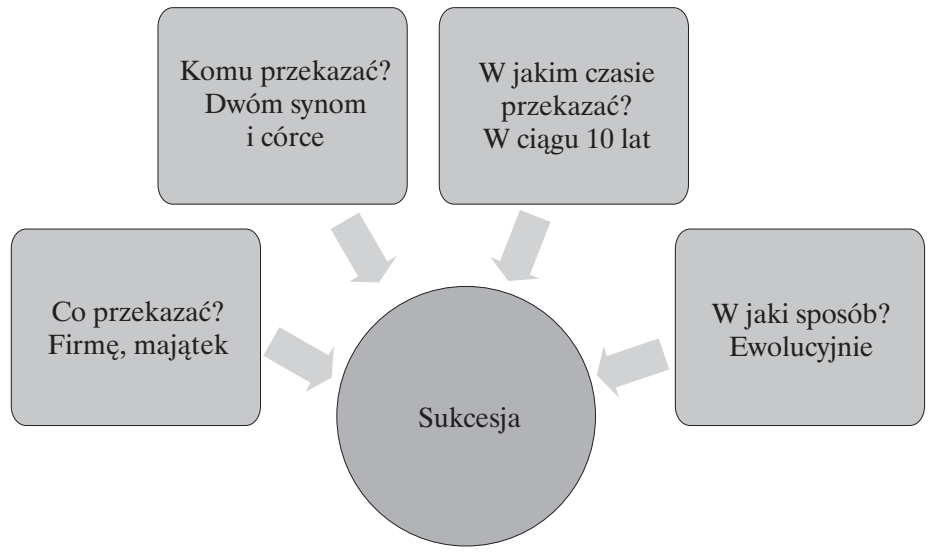

Źródło: opracowanie własne.

Wydział Zarządzania UW DOI 10.7172/1733-9758.2015.18.7 
pierwszy raz, co powoduje, że będzie on wyjątkowy pod każdym względem oryginalny.

Przechodząc do analizy samego procesu, należy przede wszystkim od odpowiedzieć na cztery kluczowe pytania dotyczące sukcesji biznesu rodzinnego.

Najważniejsze wydaje się pytanie: Co przekazać? Jak wcześniej wspomniano, największą wartość dla przedsiębiorstwa mają nieruchomości inwestycyjne, ponieważ oprócz tego, że mają one wysoką wartość materialną w przypadku sprzedaży, dostarczają bieżącego kapitału do finansowania działalności przedsiębiorstwa. Ponadto firma dysponuje majątkiem ruchomym (samochody, komputery, wyposażenie sklepów itd.), którego wartość jest równie znaczna. Istnieje jeszcze wartość samego przedsiębiorstwa - ponad 20 lat zaufania jego interesariuszy.

Komu przekazać? Biorąc pod uwagę przywiązanie właściciela do wartości rodzinnych oraz do równego traktowania każdego dziecka, jest trzech potencjalnych sukcesorów. Ważnym czynnikiem łączącym rodzeństwo jest jedność oraz tożsamy system wartości.

Największą niewiadomą jest czas. Proces sukcesji przedsiębiorstwa zależy od tego, jak potoczy się kariera zawodowa dzieci właściciela. Warto też podkreślić, że im starsza jest osoba zarządzająca, tym większa jest presja społeczna oraz psychiczna, pod którą znajduje się właściciel. Tym samym podświadomy opór przed zmianą oraz poczucie zagrożenia potęgują się i mogą w konsekwencji zakłócić proces sukcesji (Sułkowski i Marjański, 2009, s. 46). Biorąc pod uwage powyższe oraz świadomość właściciela, że z każdym rokiem będzie coraz trudniej przekazać przedsiębiorstwo, członkowie rodziny zawarli nieformalną umowę, stwierdzająca, iż formalne przekazanie przedsiębiorstwa odbędzie się $\mathrm{w}$ przeciągu następnych 10 lat.

Sposób przeprowadzania sukcesji jest zdecydowanie ewolucyjny; kolejne kroki są zaplanowane i przeprowadzane według wcześniejszych założeń. Taką ocenę potwierdza analiza, określająca, na jakim etapie znajduje się przedsiębiorstwo w procesie sukcesji.

Odnosząc się do koncepcji dotyczącej etapów przeprowadzania sukcesji (rysunek 3), trzeba zaznaczyć, że w rozważanym przypadku dwa pierwsze etapy zostały już zrealizowane. Obecnie przedsiębiorstwo znajduje się na trzecim etapie, którym jest edukacja. Ostatnim etapem, do którego zmierza analizowana firma rodzinna, jest sukcesja właściwa, polegająca na formalnej zmianie zarządzającego przedsiębiorstwem.

Pierwszym sygnałem, świadczacym o tym, iż w przyszłości może zaistnieć proces dziedziczenia przedsiębiorstwa, były narodziny pierwszego dziecka. Narodziny kolejnych dzieci umacniały we właścicielu i jego małżonce tę decyzję. $\mathrm{Z}$ uwagi na bliskość przedsiębiorstwa od miejsca zamieszkania rodziny, dzieci stosunkowo często przebywały na terenie firmy, jednocześnie uczestnicząc $\mathrm{w}$ prowadzeniu działalności. W związku z tym życie firmy oraz rodziny stosunkowo wcześnie zostało ze sobą powiązane. Początkowo dzieci były zbyt młode, by zrozumieć zasady funkcjonowania przedsiębiorstwa, jednak od początku następowało mimowolne, najpierw nieświadome, zapoznawanie się z jego specyfiką. $\mathrm{Z}$ biegiem czasu wszystkie zdarzenia stawały się coraz bardziej zrozumiałe dla najmłodszych członków rodziny, aż w końcu również ich decyzje okazały się niezbędne w prowadzeniu działalności.

Etap selekcji sukcesorów, zrealizowany przez właściciela, odbył się zgodnie $\mathrm{z}$ zasadą: dla każdego po równo i tym samym zostało wyznaczonych troje sukcesorów. Charaktery oraz osobowości tych osób uzupełniają się, a każdemu z nich zależy na tym, by nie zaprzepaścić tego, co wypracował obecny właściciel. Brak konfliktów między sukcesorami stanowi bardzo ważny element, niewątpliwie ułatwiający proces przekazywania przedsiebiorstwa.

Obecnie przedsiębiorstwo znajduje się na trzecim etapie, którym jest edukacja. Edukacja sukcesorów w przypadku tego przedsiębiorstwa trwa od momentu rozpoczęcia ich edukacji na uczelniach wyższych. Następcy nabywają wiedzę niezbędną do prowadzenia przedsiębiorstwa, uczą się współpracy z innymi. Ponadto uczestniczą w życiu przedsiębiorstwa, poznaja jego tajniki oraz kluczowych interesariuszy. Właściciel stara sie motywować członków rodziny do uczestnictwa w podejmowaniu każdej kluczowej decyzji.

Celem każdego z wymienionych etapów było przygotowanie gruntu do finalnego dokonania sukcesji oraz przekazania firmy młodszemu pokoleniu. Ostatni etap planowany jest w przeciągu dziesięciu lat. 


\section{Analiza szans i zagrożeń biznesu rodzinnego}

Największą szansą na przetrwanie przedsiębiorstwa są przede wszystkim silne więzy rodzinne i wzajemne poszanowanie uczestników firmy rodzinnej. Każdy dorosły członek rodziny jest zaangażowany w działalność podmiotu i ponosi za niego odpowiedzialność. Zrozumienie i dobre relacje oraz współpraca między zainteresowanymi powodują, że w sytuacjach kryzysowych przedsiębiorstwo jest w stanie sobie $\mathrm{z}$ nimi poradzić. Co więcej, należy podkreślić, że po przeanalizowaniu macierzy przedstawionej przez Sułkowskiego, gdzie zmiennymi są: gotowość seniora lub jej brak do akceptacji wizji juniora oraz gotowość juniora lub jej brak do przejęcia władzy organizacyjnej (Sułkowski, 2005, s. 237), można stwierdzić, iż w danym przypadku istnieje zarówno gotowość seniora, jak i juniorów do przejęcia zarządzania przedsiębiorstwem. Stąd też ryzyko wystapienia potencjalnego konfliktu międzygeneracyjnego jest zredukowane prawie do zera.

Kolejnym atutem i szansą na rozwój przedsiębiorstwa jest ugruntowana, solidna pozycja na rynku lokalnym. Firma, jak zostało wcześniej wspomniane, ma ponad 20-letnią tradycję i stałą bazę klientów oraz odbiorców usług. Taka sytuacja stwarza bardzo trwałe podstawy dla dalszej ewolucji w kierunku rozwoju przedsiębiorstwa.

Należy również zwrócić uwage, że analizowana firma ma wykształcony, wzajemnie wspierający się kapitał ludzki w postaci aż trzech osób. Są one członkami rodziny i są w stanie poświęcić się na rzecz rozwoju przedsiębiorstwa $\mathrm{z}$ uwagi na duże przywiązanie do tradycji rodzinnej. Kluczowy jest dla nich rozwój przedsiębiorstwa przy jednoczesnym zapewnieniu jego stabilności. Dodatkową korzyścią, w kontekście rozwoju przedsiębiorstwa, jest fakt, że nie mają problemu z komunikacją wewnątrzorganizacyjną oraz z podziałem pracy.

Przedsiębiorstwa rodzinne moga w swoim rozwoju korzystać również z pomocy oraz współpracy z coraz liczniejszymi organizacjami wspierającymi, zaś ich zarządzający uczestniczą w licznych szkoleniach oferowanych przez urzędy pracy oraz inne instytucje wspierane $\mathrm{z}$ programów unijnych (Latoszek, 2008, s. 68-69). Analizowana firma obecnie nie wykorzystuje takiej formy wsparcia.
Dla opisywanego przedsiębiorstwa rodzinnego dużym atutem jest również lokalizacja nieruchomości. Jest to ścisłe centrum miasta, co powoduję, że ich ceny stale utrzymuja sie na wysokim poziomie. Dodatkowo w pobliżu planowane są duże inwestycje. W związku z tym istnieje realna szansa na wzrost poziomu czynszów najmu, a tym samym przychodów biznesu rodzinnego.

Pierwszym zagrożeniem jest zasięg działalności, który obejmuje głównie inwestycje lokalne. Wąsko zdywersyfikowany portfel nieruchomości powoduje problem $\mathrm{z}$ rozszerzaniem działalności, a w przyszłości może zablokować dalszy rozwój.

Kolejne zagrożenie związane jest z możliwa zmiana charakteru oraz osobowości najbliższych uczestników przedsiębiorstwa poprzez wpływ przyszłych małżonków. Obecnie wykształcone cechy osobowościowe powodują, że takie zagrożenie jest niewielkie, ale teoretycznie występuje, zatem nie można go pominąć.

Następnie może wystąpić zjawisko nepotyzmu, ponieważ sukcesorzy przedsiębiorstwa nade wszystko cenią sobie rodzine, co dla ludzi z zewnątrz, którzy będą z nimi współpracowali, może być trudne do zaakceptowania.

Zagrożeniem dla dalszego istnienia może być także fakt, że firma działa bez formalnie spisanej strategii długoterminowej. Członkowie rodziny sa zgodni co do obecnego zakresu działalności firmy, ale w przyszłości, w obliczu zmiany pokoleniowej, koncepcja może być inna i może zabraknąć jasnej wizji dalszego rozwoju.

$\mathrm{Z}$ uwagi na fakt, że przedsiębiorstwo zalicza sie do kategorii małych i średnich, trzeba wskazać również na bariery związane nie tylko z sukcesją. D. Storey stworzył klasyfikację barier występujących w MSP. Według niego są to: bariera finansowa, zarządzania i popytu (Storey, Greene, 2011, s. 144).

Patrząc przez pryzmat całego przedsiębiorstwa, należy nadmienić, iż najpoważniejsza przeszkoda dla dalszego rozwoju może być bariera finansowa, ponieważ firma jest mała, stąd jej wiarygodność dla banków jest niska. Bariera zarządzania jest natomiast znaczaco zniwelowana, ponieważ sukcesorzy są ludźmi wykształconymi, znającymi specyfike przedsiebiorstw rodzinnych. Zagrożeniem jest z kolei popyt, bowiem trudno przewidzieć, jak będzie się rozwijał lokalny rynek nieruchomości. 
Zaletą jest zaś położenie wynajmowanych lokali - w centrum. Może się jednak okazać, iż cena najmu będzie mniejsza i tym samym przychody przedsiębiorstwa się również zmniejszą.

Ostatnim zjawiskiem, które może wystąpić i stanowić jednocześnie realne zagrożenie dla ciągłości przedsiębiorstwa jest fakt, że obecni sukcesorzy pracują w firmach zewnętrznych. Być może otrzymają na tyle atrakcyjne kontrakty, że będą preferowali pracę $\mathrm{w}$ obcym podmiocie, a nie podejmowanie trudu działania na własną rękę. Może też okazać się, że z całej trójki sukcesorów pozostaną dwie osoby lub jedna.

Podsumowując: analizowane przedsiębiorstwo ma szanse na dalszy rozwój, jednocześnie jednak nie można zapominać o występujących zagrożeniach. Biorąc je pod uwagę, zarządzający muszą rozważać różne scenariusze działania. Ważne jest, żeby skupić się na strategii rozwoju, jednocześnie nie zapominając o przyszłych potrzebach (Grossman 2011, s. 48-49). Szanse należy tak wykorzystać, aby pojawiające się w przyszłości potrzeby zostały jak najlepiej zrealizowane.

\section{Członkowie rodziny o firmie}

Każdemu z członków rodziny zostały zadane dwa pytania: Co sądzisz o biznesie rodzinnym? Czy uważasz, że przedsiębiorstwo poradzi sobie z sukcesją władzy i własności na kolejne pokolenia? Jedynie Anna nie udzieliła na nie odpowiedzi. Poniżej przytoczone są odpowiedzi członków rodziny.

Właściciel: „Uważam, że nasze przedsiębiorstwo jest bardzo stabilne. Aczkolwiek teraz jest znacznie ciężej niż było kiedyś. $\mathrm{O}$ wiele więcej trzeba się natrudzić, żeby dobrze zarobić. Mieliśmy to szczęście, że udało się nam być zawsze na czasie, podążać za rynkiem. Teraz jestem już starszy i nie mam tyle siły co wcześniej, dlatego sam już dawno zacząłem myśleć o oddaniu przedsiębiorstwa młodszemu pokoleniu. Niech pokażą, czego się nauczyli i czy potrafią sobie poradzić z trudami prowadzenia przedsiębiorstwa. Według mnie firma jest bardzo dobrze przygotowana do sukcesji. Zarówno Tobiasz, jak i Piotr bardzo dobrze znają przedsiębiorstwo. Ustaliliśmy, że w ciagu najbliższych lat przejmą przedsiębiorstwo, a mi zapewnią spokojną starość".
Żona właściciela: „Nasz biznes jest bardzo dobrze poukładany przez męża. Od wielu lat pracujemy na to, żeby mieć spokojną emeryturę. Już dawno zrozumieliśmy, że na państwową emeryturę nie mamy co liczyć. Synowie oraz córka są przygotowani na prowadzenie biznesu bez nas. Oczywiście, będziemy im zawsze pomagać, w końcu to nasze dzieci. Dlatego też myślę, że nie będzie problemu z sukcesją”.

Piotr: „Nasze przedsiębiorstwo rodzinne jest czymś wyjątkowym. Najbardziej podoba mi się to, że jesteśmy całkowitą przeciwnością powiedzenia, że $» z$ rodziną najlepiej wychodzi się na zdjęciach «. My tworzymy zgrany zespó1, który zapewnia, że nasz biznes całkiem dobrze prosperuje. Wydaje mi się, że jesteśmy dobrze przygotowani, czasem mam też wrażenie, że tak naprawdę to my podejmujemy decyzje, a tata tylko wykonuje dyspozycje. Oczywiście, bez jego zmysłu do biznesu pewnie nic by z wielu pomysłów nie wyszło. Najważniejsze, że jest z nami i ciagle nas uczy, jak zarządzać, żeby przetrwać. Myślę, że damy radę także bez taty zarządzać przedsiębiorstwem, ale dodam, że przy strategicznych decyzjach zawsze zapytamy go o zdanie".

Analiza studium przypadku, jakim jest wspomniane przedsiębiorstwo rodzinne, potwierdza opinie zawarte w cytowanych wypowiedziach. Obecna sytuacja jest stabilna w większości aspektów biznesu rodzinnego. Sukcesja jest przeprowadzana w sposób prawidłowy, a wsparcie rodziców oraz odpowiedzialność każdego członka rodziny zaangażowanego w działalność firmy pozwalają rokować pomyślne dokończenie procesu dziedziczenia. Wydaje się, iż w przypadku opisywanej firmy sukcesja doprowadzi do jej dalszego rozwoju, a nie upadku. Dobrym przykładem dla dążenia do podtrzymywania tradycji rodzinnych są przedsiębiorstwa takie jak BMW, Michelin czy Porsche (Jabłoński, 2009), których historia i rozwój pokazują, że nawet wielkie firmy mogą być utrzymywane w rękach jednej rodziny.

\section{Ocena sukcesji w firmie Romex}

Przedstawiony opis przypadku, skonfrontowany z założeniami teoretycznymi, daje pozytywny obraz przedsiębiorstwa Romex. W pierwszej kolejności należy zwrócić uwagę na obecnego właściciela firmy. Jednym $\mathrm{z}$ jego celów jest doprowa- 
dzenie w przyszłości do sukcesji. Realizacja tego celu przejawia się w przygotowywaniu kolejnego pokolenia do przejęcia firmy oraz, co ważne, w założeniu kontynuowania działalności. Dlatego nie podejmuje on pochopnych działań (np. zaciąganie kredytów, agresywne strategie inwestycyjne), a raczej dąży do zapewnienia stabilności i stałego wzrostu, ponieważ jest świadomy złożoności i czasu trwania procesu sukcesji.

Strategicznymi elementami dla ciągłości działania przedsiębiorstwa są wizja i misja firmy. Obecnie właściciel koncentruje się na stabilnym finansowaniu działalności niwelującym ryzyko prawie do zera. Taki model inwestycji jest korzystny dla kolejnego pokolenia, ale niejednoznaczne jest, czy jest on korzystny dla dalszego funkcjonowania firmy. Na pewno trzeba rozważyć kilka wariantów rozwoju i spróbować stworzyć strategię, której misja i wizja będą dobre zarówno dla samego procesu sukcesji, jak i dla przedsiębiorstwa.

Kolejną istotną determinantą udanej sukcesji, która występuje także w firmie Romex, jest nastawienie i chęć kolejnego pokolenia do przejęcia oraz dalszego prowadzenia przedsiębiorstwa. Brak konfliktu międzygeneracyjnego świadczy też o wzajemnym poszanowaniu się członków rodziny. Właściciel z jednej strony ma poczucie odpowiedzialności za losy firmy, ale jednocześnie chce jak najwięcej informacji przekazać następnemu pokoleniu, żeby potrafiło sobie poradzić w trudnych, kryzysowych sytuacjach. Głównym celem właściciela jest pozostawienie firmy w rękach rodziny najdłużej, jak to będzie możliwe. Następcy mają podobne nastawienie, ponieważ utrzymanie rodzinnego biznesu w dobrej kondycji to główny cel, który chcą realizować po przejęciu zarządzania. Wspólna determinacja pozwala pozytywnie patrzeć w przyszłość oraz realizować plany. Wydaje się jednak, że aby zapewnić powodzenie sukcesji, wspólna wola obu stron musi wynikać z wewnętrznej motywacji, a nie być jedynie skutkiem presji czy braku alternatywy.

Następnie należy zauważyć, że proces sukcesji jest w przypadku analizowanego przedsiębiorstwa rodzinnego odpowiednio przemyślany. Sposób przekazania firmy jest zaplanowany, a jedyną wadą tego rozwiązania może być założenie, że całe rodzeństwo będzie zajmowało się firmą rodzinną. Należałoby przygotować kilka scenariuszy rozwiązań, by uniknąć sytuacji, kiedy sukcesja będzie stanowiła dla członków rodziny problem. Pomimo stabilnych fundamentów obecna sukcesja nie zapewni też firmie korzyści finansowych. Na wysoka efektywność działania przedsiębiorstwa miałaby niewątpliwie znacznie większy wpływ sukcesja pojmowana jako stały element strategii firmy rodzinnej.

Kolejne pokolenia powinny być świadome swojej roli, jaką odgrywają w łańcuchu sukcesji. Powinny także jeszcze przed przejęciem firmy pomyśleć o ewentualnym kolejnym pokoleniu oraz przygotowaniu go do zrealizowania głównego celu, jakim jest przejęcie przedsiębiorstwa rodzinnego. Takie podejście zapewnia kontynuację działalności i umożliwia pozostawienie firmy w rękach jednej rodziny. Z perspektywy samego przedsiębiorstwa jest to również korzystne, ponieważ mocniejsza jest tradycja i przywiązanie, co pozwala liczyć na pełne zaangażowanie i niedopuszczenie do upadku. W przeciwnym razie, oprócz konsekwencji finansowych pojawiają się również negatywne skutki, mające ujemny wpływ na psychikę kolejnych pokoleń. Będzie to m.in. deprecjonowanie własnych osiągnięć, wynikające z fałszywej analizy zaistniałej sytuacji. Częste jest bowiem uogólnianie niepowodzeń, podporządkowane następującemu tokowi myślenia: firma tyle lat funkcjonowała w jednej rodzinie, jednak jeśli nam się nie udało i firma została zlikwidowana, to jesteśmy gorsi. Wydaje się, że w obecnej sytuacji w analizowanym przedsiębiorstwie korzystniejsze byłoby myślenie o charakterze długofalowym, skupiające się nie tylko na dziedziczeniu, ale także na dalszym rozwoju firmy.

\section{Zakończenie}

Sukcesja jest co do zasady jedną $\mathrm{z}$ charakterystycznych cech firm rodzinnych, które stanowią ważny segment gospodarki. Statystyki wskazują bowiem, że około $10 \%$ PKB Unii Europejskiej (www.europeanfamilybusinesses.eu/home) wytwarzane jest przez takie właśnie podmioty. Ponadto oferują one wiele miejsc pracy. Niestety, pomimo ich klarownych zalet, państwo polskie oraz inne instytucje wspierają je tylko w ograniczonym zakresie.

Ciekawa, ogólnoświatowa inicjatywa skierowana do firm rodzinnych została zapoczątkowana w 1989 r. przez szwajcar- 
ską organizację Family Business Network (www.fbn-i.org), której mottem działania jest „By families, for families”. Europejskim odpowiednikiem takiej organizacji non-profit jest European Family Business (www.europeanfamilybusinesses.eu).

Warto również podkreślić, że firmy rodzinne zyskały na znaczeniu w ciągu ostatnich trzydziestu lat. Inicjatywy podejmowane przez Gallo w Hiszpanii czy przez Bliklego w Polsce pozwalają na lepsze wsparcie przedsiębiorczości rodzinnej. Trzeba jednak wyraźnie stwierdzić, że wsparcie to jest na razie ograniczone głównie przez brak zaangażowania ze strony państwa. To zaś sprawia, iż przedsiębiorcy rodzinni zdani są na własne umiejętności oraz doświadczenia zwłaszcza podczas procesu sukcesji.

Zgodnie $\mathrm{z}$ przedstawioną we wstępie tezą należy stwierdzić, że sukcesja to ważny element biznesu rodzinnego, wymagajaccy długofalowego planowania.

Jak zaznaczył wybitny polski specjalista, twórca wielu publikacji w dziedzinie sukcesji, Andrzej Marjański (2012): „Posiadanie dobrego planu międzygeneracyjnego umożliwia w większości przypadków utrzymanie przedsiębiorstwa $\mathrm{w}$ dobrej kondycji oraz zachowanie właściwych stosunków rodzinnych. Przygotowanie planu sukcesji pozwoli na określenie klarownego obrazu organizacji oraz wprowadzenie porządku co do roli rodziny i uniknięcia konfliktów o własność i zarzadzanie".

Każde przedsiębiorstwo charakteryzuje się specyficznymi cechami. Dlatego też nie istnieją uniwersalne modele przeprowadzania sukcesji. Ze statystyk wynika, że z każdym kolejnym pokoleniem prawdopodobieństwo sukcesji w firmie rodzinnej jest coraz mniejsze. Wiąże się to między innymi z tym, że im więcej potencjalnych sukcesorów, tym trudniej podzielić między nich majątek i utrzymać jedność. Ponadto istotną barierą są bardzo częste konflikty międzygeneracyjne, które w skrajnych przypadkach mogą całkowicie uniemożliwić proces sukcesji.

$Z$ jednej strony dziedziczenie może być drogą do rozwoju przedsiębiorstwa, szczególnie w pierwszych pokoleniach zarządzających przedsiębiorstwem rodzinnym, gdzie młode osoby mogą bardziej efektywnie adaptować się do aktualnych wymagań rynku.

$\mathrm{Z}$ drugiej zaś strony może wystąpić sytuacja, w której sukcesja będzie zbyt trudna lub niemożliwa do przeprowadzenia i w konsekwencji doprowadzi do upadku firmy bądź sprzedaży jej podmiotom zewnętrznym. Odnosząc się do sukcesji, nie sposób pominąć słów prof. Bliklego: „Zysk nie jest celem, choć jest koniecznością. Zysk jest wynagrodzeniem kapitału, tak jak płaca jest wynagrodzeniem dla pracy. Powtarzam - zysk nie jest celem. Celem jest trwanie" (Szablewski, Nie zysk, a trwanie...).

Odnoszac sie do samego procesu sukcesji, należy pamiętać, że jest to jeden z elementów zarządzania firmą rodziną. Tym samym wszystkie funkcje, takie jak planowanie, organizowanie, motywowanie oraz kontrola, są ważne $\mathrm{z}$ punktu widzenia poprawności przeprowadzenia procesu dziedziczenia, aczkolwiek, podobnie jak w innych dziedzinach, najważniejszy jest pierwszy etap, ponieważ zapewnia on skuteczność sukcesji. Przedsiębiorstwo musi dokładnie zaplanować wszystkie możliwe scenariusze, wybór sukcesora (lub sukcesorów), jego edukację oraz wprowadzenie do firmy, tak żeby stworzyć wartość dodaną dla przedsiębiorstwa rodzinnego.

Sukcesja nie jest prostym procesem i wymaga poświęcenia dużej ilości czasu w celu zapewnienia odpowiedniego, wysokiego poziomu jej przeprowadzenia. Zaleca się, aby na początku sukcesji opowiedzieć na cztery kluczowe pytania: co, komu, kiedy i w jaki sposób przekazać.

Złożoność procesu powoduje, że każda z firm znajdować się może na innym jego etapie. Jedne przedsiębiorstwa będą inicjować proces wśród potencjalnych sukcesorów, drugie po wybraniu następcy będą skupione na jego edukacji, kolejne natomiast będą dokonywać sukcesji właściwej. Analizujac temat sukcesji, należy także podkreślić jej wieloaspektowość.

Obszarami krytycznymi są: przedsiębiorstwo, dziedzictwo oraz optymalizacja formalna. Z ostatnim wiąże się aspekt majątkowy, który wymaga opracowania dokładnej strategii przeniesienia własności na kolejne pokoleniu w celu zapewnienia dalszego rozwoju przedsiębiorstwa. Bardzo duże znaczenie dla powodzenia procesu sukcesji ma również postawa sukcesora.

Optymalny czas sukcesji jest pojęciem względnym, ale na pewno sukcesja to proces długofalowy, wymagający solidnych podstaw. Jednym z głównych wyznaczników długości procesu jest wiek obecnych właścicieli. Wydaje się, że sukcesja w przy- 
toczonym studium przypadku jest przeprowadzana bez większych przeszkód. Obecnie firma znajduje się na etapie edukacji potencjalnych sukcesorów.

Odpowiadając na pytanie badawcze postawione we wstępie artykułu, można stwierdzić, że firmie nie grozi upadek. Przede wszystkim mocnym fundamentem jej istnienia są silne więzy rodzinne, dzięki czemu wśród członków rodziny jest w dużym stopniu wykształcone poczucie odpowiedzialności za losy firmy. Istotny jest również fakt, iż w przedsiębiorstwie nie występuje konflikt międzypokoleniowy. Wzajemne zrozumienie pozwala z optymizmem patrzeć $\mathrm{w}$ przyszłość.

\section{Bibliografia}

Budziak, T. (2012). Sukcesja w rodzinie biznesowej. Spojrzenie praktyczne. Warszawa: Poltext.

Chrisman, J.J., Chua, J.H. i Steier, L.P. (2011) Resilience of Family Firms: An Introduction. Entrepreneurship Theory and Practice, 35(6).

Czakon, W. (2011). Zastosowanie studiów przypadków w badaniach nauk o zarządzaniu. W W. Czakon (red.), Podstawy metodologii badań wźnaukach o zarzadzaniu. Warszawa: Wolters Kluwer Polska.

Gersick, K.E., Davis, J.A., Mc Collom Hampton, M. i Lansberg, I. (1997). Generation to Generation Life Cycles of the Family Business, Boston: Harvad Business School Press.

Grossman, R.J. (2011). 7 Ways to improve Succession Plans. HR Magazine, 56(6).

http://kodywartosci.pl/kw_raport.pdf

http:/www.fbn-i.org/fbn/web.nsf

Jabłoński, I. (2009). Znaczenie i rola przedsiębiorstw rodzinnych. Warszawa: Centrum im. A. Smitha.

Jeżak, J., Popczyk, W. i Winnicka-Popczyk, A. (2004). Przedsiębiorstwo rodzinne: Funkcjonowanie i rozwój. Warszawa: Difin.

Kostera, M. (2003). Antropologia organizacji. Metodologia badań terenowych. Warszawa: Wydawnictwo Naukowe PWN.

Kotlar, J. i De Massis, A. (2011). Goal Setting in Family Firms: Goal Diversity, Social Interactions, and Collective Commitment to Family-Centered Goals. Entrepreneurship Theory and Practice, 37(6), 1263-1288.

Kowalewska, A. (2009). Badanie firm rodzinnych. Raport końcowy. Warszawa: PARP.

Kowalewska, A. (2009), Firmy rodzinne w polskie gospodarce - szanse $i$ wyzwania. Warszawa: PARP.
Latoszek, E. (2008). Szanse rozwoju małych i średnich przedsiebiorstw w Polsce. W: E. Latoszek (red.), Finansowanie MSP $w$ Polsce ze środków finansowych UE jako czynnik wplywający na konkurencyjność przedsiębiorstw. Warszawa: Oficyna Wydawnicza SGH.

Lewandowska, A., Greser, J. i Jakubowski, J. (2012). Sukcesja w firmie rodzinnej. W: K. Bryczkowska, M. Olszewska i M. Mączyńska (red.), Firma $w$ rodzinie czy rodzina $w$ firmie, Metodologia wsparcia firm rodzinnych. Warszawa: PARP.

Longenecker, J. i Schoen, J. (2002). Management Succession in the Family Business. W: C. Aronoff, J. Astrachan, J. Ward (red.), Family Business Sourcebook. Georgia: Family Enterprise Publishers.

Lumpkin, G.T. i Brigham, K.H. (2011). Long-Term Orientation and Intertemporal Choice in Family Firms. Entrepreneurship Theory and Practice, 35(6), 1149-1169.

Marjański, A. (2012). Sukcesja jako wyróżnik przedsiębiorstwa rodzinnego. Przedsiębiorczośc i Zarzadzanie, XIII(7).

Marjański, A. (2010). Badanie sukcesji w małych przedsiębiorstwach rodzinnych w Polsce. Problemy Zarzadzania, 8(4), 87-106.

Stavrou, E. (1999). Succession in family businesses: Exploring the effects of demographic factors on offspring intentions to join and take over the business. Journal of Small Business Management, 37(3), 43-61.

Storey, D.J. i Greene F.J. (2011). Small Business and Entrepreneurship. Prentice Hall: Financial Times.

Sułkowski, Ł. i Marjański, A. (2009). Firmy rodzinne. Jak osiagnać sukces $w$ sztafecie pokoleń. Warszawa: Poltext.

Sułkowski, Ł. (2005). Sukcesja i zarządzanie personelem w przedsiebiorstwie rodzinnym. W: Ł. Sułkowski (red.), Determinanty rozwoju przedsiębiorstw rodzinnych $w$ Polsce. Toruń: TNOiK.

Surdej, A. i Wach, K. (2010). Przedsiębiorstwa rodzinne wobec wyzwań sukcesji. Warszawa: Difin.

Szablewski, A. Nie zysk, a trwanie - Andrzej Blikle o celu i cechach firmy rodzinnej. Pozyskano z: http://www.ora.et.labora.pl/index.php?s=czytelnia$\& \mathrm{id}=133 \& \mathrm{pdz}$

www.europeanfamilybusinesses.eu

www.fbn-i.org

Zalecenie Komisji z dnia 6 maja 2003 r. dotyczące definicji przedsiębiorstw mikro, małych i średnich, nr 2003/361/EC. 